\title{
ENGARUH BRAND EQUITY TERHADAP LOYALITAS NASABAH PT. BANK PANIN DUBAI SYARIAH, TBK. CABANG PALEMBANG
}

\author{
Oleh : \\ Kms Afandi Abdullah \\ Bank Panin Dubai Syariah Palembang \\ Email : kms.afandi@yahoo.com, \\ Luis Marnisah \\ Fakutas Ekonomi UIGM \\ Email : luis_marnisah@uigm.ac.id \\ S.K. Hildayanti \\ Program Magister Manajemen UIGM \\ Email : fakhry@uigm.ac.id.
}

\begin{abstract}
Penelitian ini bertujuan untuk menganalisis pengaruh Brand Awareness, Brand association, perceived quality, Brand loyalty terhadap loyalitas nasabah PT. Bank Panin Dubai Syariah Bank, Tbk. Cabang Palembang, secara parsial dan secara bersama terhadap loyalitas nasabah PT. Bank Panin Dubai Syariah Bank, Cabang Palembang. Didisain menggunakan analisis kuantitatif deskriptif, dengan sampel sebanyak 92 nasabah yang diambil dari 1126 nasabah dengan menggunakan Teknik Sloven. Pengumpulan data menggunakan Teknik kuesioner dan data diolah dengan tools analisis SPSS 22.

Melalui uji hipotesis dapat diketahui bahwa Brand awareness tidak dapat memengaruhi Loyalitas Pelangan dengan $\mathrm{P} 0,152>0,05$ dan t. hitung $1.445<\mathrm{t}$ tabel 1.9839 , terdapat pengaruh perceived quality terhadap loyalitas pelangan dengan signifikansi $0.038<0,05$ dan t.-hitung $1.998>t$-tabel 1.9839 , Brand loyalty berpengaruh terhadap loyalitas pelangan dengan tingkat signifikansi $0,026<0,05$ dan t. hitung 2.219>t.tabel 1.9839, brans association memengaruhi loyalitas merk dengan tingkat signifikansi 0,00<0,05 dan t hitung 3.699> t.tabel 1.9838, dan Brand Awareness,Brand association, perceived quality, Brand loyalty berpengaruh terhadap loyalitas nasabah Bank Panin Dubai Syariah signifikansi 0,00<0,05 dan F hitung 7,655> F.tabel 2.700. Benang merah penelitian bahwa; Brand Awareness tidak berpengaruh terhadap loyalitas pelanggan, Brand association, perceived quality, Brand loyalty berpengaruh terhadap loyalitas nasabah Bank Panin Dubai Syariah, dan Brand Awareness, Brand association, perceived quality, Brand loyalty berpengaruh secara bersama terhadap loyalitas nasabah Bank Panin Dubai Syariah.
\end{abstract}

Kata Kunci : Brand Awareness,Brand association, perceived quality, Brand loyaltyterhadap loyalitas

\section{LATAR BELAKANG}

Produk dari suatu perusahaan dikenal dengan mencantumkan merk atau identitas yang mudah diingat dan mempunyai nilai tinggi. Penamaan sebuah produk dalam bentuk merk menjadi faktor pendukung kelancaran dalam proses pemasaran.
Selain dari produk barang berwujud yang memenuhi kebutuhan manusia yang menginginkan juga termasuk produk adalah jasa yang akan difokuskan kedalam jasa perbankan.

Dalam kegiatan operasional bisnis perbankan terbagi dua jenis yaitu 
perbankan konvensional dan perbankan syariah. Perkembangan perbankan Islam merupakan fenomena yang menarik kalangan akademisi maupun praktisi dalam 20 tahun terakhir, tak kurang IMF juga telah melakukan kajian-kajian atas praktek perbankan Islam sebagai alternatif sistem keuangan internasional yang memberikan peluang upaya penyempurnaan sistem keuangan internasional yang belakangan dirasakan banyak sekali mengalami goncangan dan ketidakstabilan yang menyebabkan krisis dan keterpurukan konomi akibat lebih dominannya sektor finansial dibanding sektor riil dalam hubungan perekonomian dunia.

Prinsip-prinsip dasar sistem ekonomi Islam akan menjadi dasar beroperasinya bank Islam yaitu yang paling menonjol adalah tidak mengenal konsep bunga uang dan yang tidak kalah pentingnya adalah untuk tujuan komersial Islam tidak mengenal peminjaman uang tetapi adalah kemitraan / kerjasama (mudharabah dan musyarakah) dengan prinsip bagi hasil.

Menurut hasil sensus tahun 2010, $87,18 \%$ dari 237.641.326 penduduk Indonesia adalah pemeluk Islam, 6,96\% Protestan, 2,9\% Katolik, 1,69\% Hindu, 0,72\% Buddha, 0,05\% Kong $\mathrm{Hu} \mathrm{Cu}$, $0,13 \%$ agama lainnya, dan $0,38 \%$ tidak terjawab, namun ironis perkembangan perbankan syariah dalam 20 tahun terakhir masih belum menggembirakan dikarenakan share perbankan syariah terhadap share perbankan $5.3 \%$ pada tahun 2016 (Otoritas Jasa Keuangan, 2016).

Berdasarkan data Bank di Indonesia pada tahun 2016 berjumlah 118 Bank. dimana dalam kategori BUKU II terdapat 36 Bank di Indonesia. Di Palembang untuk Bank BUKU II terdapat 16 Bank terdiri dari: Bank Mayapada, Bank DKI, Bank
Ekonomi, Bank Syariah Mandiri, Bank Muamalat, Bank BNI Syariah, Bank Sinarmas, Bank Sumsel Babel, Bank Artha Graha Internasional, Rabobank, Bank BRI Syariah, Bank National NOBU, Bank Windu, Bank QNB, dan Commonwealth Bank. Secara keseluruhan struktur pasar perbankan di Palembang adalah pasar persaingan sempurna terdapat 42 Bank Umum, Syariah dan Asing dari berbagai kategori BUKU, sebagai berikut : Bank BUKU I terdapat 8 Bank, Bank BUKU II terdapat 16 Bank, Bank BUKU III terdapat 16 Bank, Bank BUKU IV terdapat 4 Bank.

Posisi Bank Panin Dubai Syariah merupakan Bank Swasta Nasional yang terdaftar sebagai Bank BUKU (Bank Umum Kegiatan Usaha) II atau bermodal inti Rp. $1 \mathrm{~T}$ sd. Rp. $5 \mathrm{~T}$, dengan strategi pemasaran yang dilakukan adalah full service excellent, dimana nasabah diberikan pelayanan prima baik dari segi sumber daya manusia dan teknologi serta produk jasa perbankan yang fleksibel sesuai kebutuhan baik dari segi tingkat bagi hasil maupun kecepatan seperti produk unggulan di Tabungan haji yang memberikan pelayanan antar jemput sampai dengan ambil porsi haji di Kementrian Agama yang di Bank lain pelayanan seperti ini belum ada.

\section{Identifikasi Masalah}

Masih terdapat persepsi masyarakat bahwa Bank Syariah, belum dikelola sepenuhnya secara Syariah, sehingga membutuhkan tim yang solid untuk dapat merubah persepsi masyarakat, nasabah Bank Syariah menjadikan investasi pada perbankan Syariah hanya sebagai alternatif, di samping tetap loyal pada perbankan konvensional, dan Brand Awareness mengenai bank yang dikelola secara syariah belum dapat memengaruhi 
perilaku konsumen perbankan Kota Palembang.

Perceived Quality tentang perbankan Syariah belum kuat memengaruhi perilaku konsumen dalam memutuskan investasi pada bank Syariah, Brand Loyalty masyarakat Kota Palembang masih besar dipengaruhioleh perbankan konvesional, dan Brand Association Bank Syariah belum menjadi pertimbangan calon konsumen dalam investasi perbankan. Beranjak dari beberapa persoalan di atas, dirasakan perlu dilakukan penelitianyang lebih mendalam dari kajian manajemen pemasaran mengenai loyalitas pelangan terhadap PT.Bank Panin Dubai Syariah Tbk Cabang Palembang yang telah beroperasisejak tanggal 15 Juni2016.

\section{Perumusan Masalah}

Perumusan masalah penelitian ini dapat dirumuskan sebagai berikut :

1. Bagaimanakah pengaruh Brand Awareness terhadap loyalitas nasabah PT. Bank Panin Dubai Syariah Bank, Tbk. Cabang Palembang?

2. Bagaimanakah pengaruh Brand association terhadap loyalitas nasabah PT. Bank Panin Dubai Syariah Bank, Tbk. Cabang Palembang?

3. Bagaimanakah pengaruh perceived qualityterhadap loyalitas nasabah PT. Bank Panin Dubai Syariah Bank, Tbk. Cabang Palembang?

4. Bagaimanakah pengaruh Brand loyaltyterhadap loyalitas nasabah PT. Bank Panin Dubai Syariah Bank, Tbk. Cabang Palembang?

5. Bagaimanakah pengaruh Brand Equity,Brand Awareness, Brand association, perceived quality, Brand loyalty secara bersama terhadap loyalitas nasabah PT. Bank Panin Dubai
Syariah Bank, Tbk. Cabang Palembang?

\section{Tujuan Penelitian}

Tujuan penelitian ini adalah untuk mengetahui:

1. Untuk menganalisis pengaruh Brand Awarenessterhadap loyalitas nasabah PT. Bank Panin Dubai Syariah Bank, Tbk. Cabang Palembang.

2. Untuk menganalisis pengaruh Brand associationterhadap loyalitas nasabah PT. Bank Panin Dubai Syariah Bank, Tbk. Cabang Palembang.

3. Untuk menganalisis pengaruh perceived quality terhadap loyalitas nasabah PT. Bank Panin Dubai Syariah Bank, Tbk. Cabang Palembang.

4. Untuk menganalisis pengaruh Brand loyaltyterhadap loyalitas nasabah PT. Bank Panin Dubai Syariah Bank, Tbk. Cabang Palembang.

5. Untuk menganalisis pengaruh Brand Equity,Brand Awareness, Brand association, perceived quality,Brand loyalty secara bersama terhadap loyalitas nasabah PT. Bank Panin Dubai Syariah Bank, Tbk. Cabang Palembang.

\section{KAJIAN PUSTAKA \\ Pengertian Tentang Brand}

Hampir setiap produk ataupun jasa yang ada saat ini memiliki merk sehingga merk menjadi satu kata yang populer digunakan sekarang ini. Akan tetapi tidak sedikit orang yang tidak mengerti akan definisi merk, sebagian orang menganggap bahwa merk hanyalah suatu nama dari produk sebagai identitas. Namun demikian, pengertian sebenarnya dari merk dari beberapa ahli. 
Menurut Kotler and Keller (2012) defines Brand as a name, term, sign, symbol, or design, or a combination of them, intended to identify the goods or services of one seller or group of sellers and to differentiate them from those of competitors.

Definisi merk lainnya menurut Aaker (1991) adalah:"Nama dan/atau symbol yang bersifat membedakan ( seperti sebuah logo, cap, atau kemasan) dengan maksud mengidentifikasikan barang atau jasa dari seorang penjual atau sebuah kelompok penjual terntentu, dengan demikian membedakannya dari barang-barang dan jasa yang dihasilkan para competitor."

Berpedoman pada pengertian di atas, bahwa Brand Equity memiliki elemen sebagai berikut Kotler and Keller (2012):memorable, meaningfull, mikable, transferable, adaptable dan protectable. Elemen-elemen dari Brand dapat membangun kekuatan perusahaan di pasar. Apabila nasabah tidak mempertimbangkan terkait informasi produk untuk mengambil keputusan pembelian, maka Brand yang kuat akan secara mudah untuk diingat oleh nasabah dan pada akhirnya dipilih.

Stretegi alternative Branding di ungkapkan dalam Kotler and Keller (2012):1. Individual or Separate family Brand Names, 2. Corporate umbrella or company Brand Name, 3. Sub Brand Name. Menurut Kotler and Keller (2012) Brands can also play a number of specific roles as part of portofolio: 1. Flankers, 2. Cash Cows, 3. Low End Entry Level, 4. High End Prestige.

Dengan demikian dapat disimpulkan bahwa Branding itu sendiri adalah upaya atau hal penting dalam strategi pemasaran suatu perusahaan pada abad 21 ini berupa Brand harus memiliki nama yang sangat kuat sehingga menghasilkan laba yang besar untuk perusahaan dan kita harus tahu dan mengerti sebelum kita memperkenalkan Brand tersebut serta selalu dapat di ingat dan mudah di ucapkan oleh nasabah. Brand yang besar akan tumbuh oleh hubungan dengan nasabah yang baik, hal tersebut penting sampai kita bisa lebih memperhatikan perspektif yang terkecil sekalipun dan relevan serta sederhana dan mengedepankan pelayanan lebih penting daripada hanya sekedar kecanggihan teknologi.

\section{Loyalitas Nasabah}

Banyak pengertian yang diberikan oleh para ahli mengenai istilah Loyalitas Nasabah. Menurut International Journal of Management (2013:236-243) Customer loyalty is the repeat purchase, referring the company to other customers (Day, 1969; Heskett, Jones, Loveman, Sasser \& Schlesinger, 1994), generates positive and measurable financial results (Duffy, 2003) and contributes to the profitability of the service providers (Anderson \& Mittal, 2000; Anderson \& Sullivan, 1993).

Istilah loyalitas sering kali diperdengarkan oleh pakar pemasaran maupun praktisi bisnis, loyalitas merupakan konsep yang tampak mudah dibicarakan dalam konteks sehari-hari, tetapi menjadi lebih sulit ketika dianalisis maknanya. Dalam banyak definisi Ali Hasan (2008) menjelaskan loyalitas sebagai berikut:

1. Sebagai konsep general, loyalitas merk menunjukkan kecenderungan konsumen untuk membeli sebuah merk tertentu dengan tingkat konsistensi yang tinggi.

2. Sebagai konsep perilaku, pembelian ulang kerap kali dihubungkan denga loyalitas merk (Brand loyality). Perbedaannya, bila loyalitas merk menceminkan komitmen psikologis 
terhadap merk tertentu, perilaku pembelian ulang menyangkut pembelian merk yang sama secara berulang kali.

3. Pembelian ulang merupakan hasil dominasi (1) berhasil membuat produknya menjadi satu-satunya alternative yang tersedia, (2) yang terus-menerus melakukan promosi untuk memikat dan membujuk nasabah membeli kembali merk yang sama.

Loyalitas nasabah merupakan salah satu tujuan inti yang diupayakan dalam pemasaran modern. Hal ini dikarenakan dengan loyalitas diharapkan perusahaan akan mendapatkan keuntungan jangka panjang atas hubungan mutualisme yang terjalindalam kurun waktu tertentu.

Nasabah dapat dijabarkan sebagai berikut, secara harafiah loyal berarti setia, atau loyalitas dapat diartikan sebagai suatu kesetiaan. Kesetiaan ini timbul tanpa adanya paksaan, tetapi timbul dari kesadaran sendiri pada masa lalu. Sedangkan konsep loyalitas nasabah lebih menekankan kepada perilaku pembeliannya.

\section{Brand Equity}

Merupakan dimensi yang membedakan suatu produk atau layanan dari suatu perusahaan dibandingkan perusahaan lainnya yang sama-sama memiliki tujuan untuk menyediakan kebutuhan nasabah. Perbedaan tersebut dapat dibentuk melalui simbolik, emosional, terwujud dan tidak berwujud. Ekuitas merk (Brand Equity) dapat mempengaruhi rasa percaya diri nasabah dalam mengambil keputusan pembelian. Ekuitas merk (Brand Equity) memiliki potensi untuk menambah nilai bagi perusahaan dengan membangkitkan arus kas marginal lewat enam cara yaitu:

1. Brand Equity dapat menguatkan program memikat para konsumen baru atau merangkul kembali nasabah Lama.
2. Brand Equity memungkinkan margin yang lebih tinggi dengan memungkinkan harga optimum dan mengurangi ketergantungan terhadap promosi.

3. Brand Equity dapat memberikan landasan pertumbuhan lewat perluasan merk.

4. Brand Equity dapat memberikan dorongan dalam saluran distribusi.

5. Brand Equity dapat memberikan keuntungan kompetitif yang sering menghadirkan rintangan nyata terhadap competitor.

6. Brand loyalty merupakan salah satu dimensi Ekuitas merk (Brand Equity) yang sangat penting

Peran Brand Awareness dalam Brand Equity tergantung pada tingkat pencapaian kesadaran dalam benak konsumen. Durianto, Sugiarto (2004) menyatakan bahwa Kesadaran merkdapat dibangun dan diperbaiki melalui cara-cara berikut:

1. Pesan yang disampaikan oleh suatu Brand harus mudah diingat oleh konsumen.

2. Pesan yang disampaikan harus berbeda dengan produk lainnya serta harus ada hubungan antara Brand dengan kategori produknya.

3. Memakai slogan maupun jingle lagu yang menarik sehingga membantu konsumen mengingat Brand.

4. Jika suatu brand memiliki simbol, hendaknya simbol tersebut dapat dihubungkan dengan brandnya.

5. Perluasan nama brand dapat dipakai agar brand semakin diingat konsumen.

6. Kesadaran merkdapat dperkuat dengan memakai suatu isyarat yang sesuai dengan kategori produk, brand, maupun keduanya.

7. Melakukan pengulangan untuk meningkatkan pengingatan, karena 
membentuk ingatan adalah lebih sulit dibanding membentuk pengenalan.

\section{Brand Association}

Segala sesuatu yang berkaitan dengan ingatan mengenai sebuah merk. Asosiasi merk (Brand association) berkaitan erat dengan Brand Image, yang didefinisikan sebagai serangkaian asosiasi merk dengan makna tertentu. Asosiasi merk memiliki tingkat kekuatan tertentu dan akan semakin kuat seiring dengan bertambahnya pengalaman konsumsi dengan merk spesifik.

Pada umumnya asosiasi merk terhadap merk menjadi pijakan konsumen dalam keputusan pembelian dan loyalitas pada merk tersebut. Dalam prakteknya didapati banyak sekali kemungkinan variasi dari asosiasi merk yang dapat memberikan suatu nilai bagi suatu merk, dipandang dari sisi perusahaan maupun dari sisi pengguna. Berbagai fungsi asosiasi merk tersebut adalah :

1. Help process/retreive information
(membantu proses penyusunan
informasi)
2.Differentiate (membedakan) Suatu
kesan dapat memberikan landasan yang penting bagi upaya pembedaan suatu merk dari merk lain.

3. Reason to buy (alasan pembelian) Asosiasi merk (Brand association)s membangkitkan berbagai atribut produk ataumanfaat bagi konsumen (costumer benefits) yang dapat memberikan alasan spesifik bagi konsumen untuk membeli dan menggunakan merk tersebut.

\section{Create possitive attitude/feelings} (menciptakan sikap atau perasaan positif) Beberapa Asosiasi merk (Brand association)s mampu merangsang suatu perasaan positif yang pada gilirannya merembet ke merk yang bersangkutan.
Asosiasi merk (Brand association)s tersebut dapat menciptakan serta mengubah pengalaman tersebut menjadi sesuatu yang lain daripada yang lain.

5.Basis for extensions (landasan untuk perluasan) Suatu Asosiasi merk (Brand association)s dapat menghasilkan landasan bagi suatu perluasan dengan menciptakan suatu rasa kesesuaian (sense of fit) antara merk dan sebuah produk baru atau dengan menghadirkan alasan untuk membeli produk perluasan tersebut.

\section{Perceived Quality}

Keller (2008) menyatakan bahwa persepsi kualitas dapat didefinisikan sebagai persepsi konsumen terhadap keseluruhan kualitas, atau keunggulan relatif dari sebuah produk atau jasa terhadap alternatif-alternatif yang relevan sesuai dengan tujuan yang ingin dicapai.

Persepsi kualitas dapat didefinisikan sebagai pendapat seseorang mengenai seluruh keunggulan produk. Persepsi kualitas adalah (1). berbeda dari kualitas sesungguhnya, (2). memiliki tingkat keabstrakan yang lebih tinggi dibanding atribut spesifik dari produk, (3). sebuah penilaian global dimana pada beberapa kasus menyerupai sikap, dan (4). penilaian yang berasal dari konsumen berdasar apa yang ada dalam ingatannya.

\section{Brand Loyalty}

Brand loyalty Merupakan dasar dari Ekuitas merk yang diciptakan oleh beberapa faktor utama seperti pengalaman penggunaan. Dengan mempertimbangkan loyalitas merk sebagai inti dari Ekuitas merk. Bila loyalitas meningkat merk meningkat, kerentanan kelompok nasabah dari serangan kompetitif bisa dikurangi. 
Bila loyalitas pelanggan terhadap suatu merk meningkat, kerentanan kelompok pelanggan tersebut dari ancaman dan serangan merk produk pesaing dapat dikurangi. Pelanggan yang loyal pada umumnya akan melanjutkan pembelian terhadap merk tersebut, walaupun dihadapkan pada banyak alternative merk.

Menurut Aaker (1991) loyalitas merk adalah suatu ukuran keterkaitan seorang pelanggan terhadap sebuah merk. Ada beberapa tingkatan dalam loyalitas merk:

1. switches, pembeli tidak loyal sama sekali, tidak tertarik pada merk perusahaan, berpindah-pindah, serta peka terhadap perubahan harga.

2. habitual buyer, pembeli yang puas terhadap produk, atau bersifat kebiasaan, sehingga tidak ada alasan untuk beralih. Setidaknya tidak mengalami ketidakpuasan.

3. satisfied buyer, pembeli yang puas, namun merka menanggung biaya peralihan (switching cost), biaya dalam waktu, uang, atau risiko kinerja berkenaan dengan tindakan beralih merk.

4. likes the brand, pembeli yang sungguhsungguh menyukai merk, menganggap merk sebagai sahabat.

5. committed buyer, pelanggan yang setia, mempunyai kebanggaan dalam menjadi pelanggan suatu merk.

\section{Hipotesis}

Berdasarkan deskripsi teoritis, penelitian terdahulu dan kerangka pemikiran sebagaimana diungkapkan di atas, dapat diajukan hipotesis sebagai berikut:
1. Terdapat
pengaruh
Brand
Awarenessterhadap loyalitas
nasabah

PT Bank Panin Dubai Syariah Bank, Tbk. Cabang Palembang.

2. Terdapat pengaruh perceived quality terhadap loyalitas nasabah PT Bank Panin Dubai Syariah, Tbk. Cabang Palembang.

3. Terdapat pengaruh Brand loyaltyterhadap loyalitas nasabah PT Bank Panin Dubai Syariah Bank, Tbk. Cabang Palembang.

4. Terdapat pengaruh variabel Asosiasi merk (Brand association) terhadap loyalitas nasabah PT Bank Panin Dubai Syariah Bank, Tbk. Cabang Palembang.

5. Terdapat pengaruh Brand Equity, Brand Awareness, Brand association, perceived quality, Brand loyalty secara bersama terhadap loyalitas nasabah PT Bank Panin Dubai Syariah Bank, Tbk. Cabang Palembang.

\section{METODOLOGI PENELITIAN}

Pada penelitian ini, desain penelitian yang digunakan adalah deskriptif yaitu mendeskripsikan variabel Brand Equity yang mempengaruhi loyalitas nasabah. Penelitian kuantitatif.

\section{Populasi dan Teknik Pengambilan Sampel}

Populasi menurut Sugiyono (2003) adalah "wilayah generalisasi yang terdiri atas obyek atau subyek yang mempunyai kuantitas dan karakteristik tertentu yang diharapkan oleh peneliti untuk dipelajari dan kemudian ditarik kesimpulannya”.

Bank Panin Dubai Syariah KC Palembang berdiri sejak tanggal 15 Juni 2016 dan nasabah ini merupakan nasabah exsisting Bank Panin Dubai Syariah. Sebelumnya Bank Panin Dubai Syariah hanya mempunyai cabang di Jawa dan memperluas perkembangan pasarnya di pulau Sumatera dengan masuk pertama 
kali di wilayah Provinsi Sumatera Selatan di Kota Palembang. Populasi dalam penelitian ini adalah seluruh nasabah Bank Panin Dubai Syariah KC Palembang sebanyak 1.126 orang, 92 diantaranya dijadikan sampel dengan menggunakan Teknik Sloven .

\section{Metode Pengumpulan Data}

Jenis Sumber Data Penelitian ini menggunakan jenis data primer. Data primer merupakan data yang diperoleh dari responden melalui penyebaran kuesioner kepada nasabah PDSB di Palembang.

\section{Metode Pengumpulan Data}

Dalam penellitian ini, penulis menggunakan metode pengumpulan data dari:Penelitian lapangan (Field Research) yang dilakukan dengan cara survey menggunakan instrument berupa kuesioner kepada responden yaitu nasabah yang datang ke kantor PDSB KC Palembang.

\section{OPERASIONAL VARIABEL}

\section{Brand Awareness}

Kesadaran Merk yang sangat tinggi dari konsumen yang tertanam dalam benak konsumen bahwa merk tersebut adalah yang terbaik dalam menentukan pilihan terhadap suatu produk.

Mengenal PDSB sebagai Bank Swasta Nasional yang terpercaya; 2. Mengenali Logo PDSB; 3. Mengetahui Lokasi PDSB di Palembang; 4. Mengetahui apabila PDSB sebelumnya adalah Bank Panin Dubai Syariah.

\section{Perceived Quality}

Kesan Kualitas yang timbul sesuai persepsi konsumen yang didapatkan berdasarkan pengalaman konsumen saat bertransaksi baik dalam pembelian barang maupun jasa terkait kualitas dan keunggulan-keunggulan perusahaan penyedia barang atau jasa tersebut. 1. Mengenal produk-produk PDSB; 2. Mengetahui produk unggulan PDSB; 3. Nasabah PDSB merasakan kemudahan-kemudahan bertransaksi di PDSB; 4. Nasabah mempercayakan pengelolaan keuangannya di PDSB.

\section{Brand Loyalty}

Konsumen tidak terpengaruh apabila produk dari merk tertentu yang berkualitas bagus mengalami perubahan harga maupun atribut karena telah nyaman dengan merk tersebut Nasabah memiliki lebih dari satu produk PDSB; 2.Nasabah memiliki layanan ebanking PDSB; 3. Nasabah menjadikan PDSB sebagai Bank yang utama untuk bertransaksi; 4. Nasabah merekomendasikan produk PDSB kepada kerabat, saudara, teman, dan rekan bisnisnya.

\section{Brand Association}

Suatu kesan konsumen yang dapat memberikan landasan penting bagi upaya pembedaan suatu merk dari merk lain dan akhirnya mempengaruhi suatu keputusan untuk memilih.

1. Nasabah merasa nyaman saat menunggu transaksi di PDSB;

2. Nasabah merasakan pelayanan yang ramah dan personal dari Frontliners dan MarketingPDSB

3. Nasabah merasa aman bertransaksi di PDSB ;

4. Nasabah senang dengan tingkat bagi hasil dan program-program dari produk PDSB.

\section{Loyalitas Nasabah}

Preferensi konsumen dalam memutuskan penggunaan atau pembelian merk tertentu dari sebuah produk secara konsisten dan terus-menerus dan tidak 
terpengaruh terhadap faktor-faktor lain yang dapat menimbulkan perilaku peralihan pemilihan merk. Konsumen telah dalam tahap yang benar-benar setia terhadap merk tertentu.

Nasabah tidak akan memilih produk yang sama dari Bank Lain diluar PDSB; 2. Nasabah memiliki lebih dari satu rekening untuk produk yang sama di PDSB; 3.Nasabahtidak terpengaruh dengan tingkat persaingan bagi hasik Tabungan maupun Deposito di Bank Lain ; 4. Nasabah akan merkomendasikan dan membantu mempromosikan PDSB.

\section{ANALISIS DAN PEMBAHASAN}

\section{Analisis Pengaruh Brand Awareness}

Terhadap Loyalitas Pelangan.

Melalui uji hipotesis dapat diketahui bahwa Brand Awarenesstidak dapat memengaruhi Loyalitas Pelangan nilai signifikansi 0,152>0,05 dan t. hitung 1.445 $<$ t.tabel 1.9839, maka penelitian tidak berhasil mengkonfirmasi anata teori penelitian dengan empiris di lapangan, sebagaimana tergambar dalam tabel di bawah

Tabel 1 :Pengaruh Brand AwarenessTerhadap Loyalitas Pelangan

\begin{tabular}{|l|c|c|c|c|c|}
\hline \multirow{2}{*}{ Model } & \multicolumn{2}{|c|}{$\begin{array}{c}\text { Unstandardized } \\
\text { Coefficients }\end{array}$} & $\begin{array}{c}\text { Standardized } \\
\text { Coefficients }\end{array}$ & \multirow{2}{*}{} & \\
\cline { 2 - 5 } & $\mathrm{B}$ & $\begin{array}{c}\text { Std. } \\
\text { Error }\end{array}$ & Beta & $\mathrm{T}$ & Sig. \\
\hline $\begin{array}{l}\text { Brand_ } \\
\begin{array}{l}\text { Awaren } \\
\text { ess }\end{array}\end{array}$ & 0.153 & 0.106 & 0.141 & 1.445 & 0.152 \\
\hline
\end{tabular}

Sumber : Output SPSS Diolah

Hasil penelitian ini ternyata tidak sama dengan penelitian Ahmad Kholid Alghofari, at.all (2009), bahwa Brand Awareness memiliki pengaruh signifikan terhadap Customer Loyalty pada jenis Merk Pasta Gigi.

Belum berpengaruhnya Brand Awareness terhadap loyalitas pelangan Bank Panin Dubai Syariah Cabang Palembang dimungkinkan karena baru beroperasi sejak tahun 2016. Kendati nasabah telah memahami bahwa Bank panin Dubai Syariah merupakan Bank swasta nasional terkemuka di kota Palembang.

Bahwa indikator variabel Brand Awareness dominan memengaruhi loyalitas pelangan adalah KM 05 yaitu Bank Panin Dubai Syariah merupakan bank swasta syariah yang pertama Go Public. Disini nasabah telah mengetahui bahwa bank Panin Dubai Syariah adalah bank swasta nasional dan sahamnya sebagaian telah milik publik

Dan indikator variabel Brand Awareness terendah dengan koefisien sebesar 2.90 yaitu Bank Panin Dubai Syariah merupakan perbankan yang dikelola menurut ketentuan Syariah. Indikator rendahnya pemahaman bahwa Bank Panin Dubai Syariah dikelola menurut ketentuan Syariah, dapat menjadi factor penyebab kesadaran merk tidak berpengaruh terhadap loyalitas pelangan.

\section{Analisis Pengaruh Perceived Quality} Terhadap Loyalitas Pelangan

Hasil uji hipotesis bahwa terdapat pengaruh perceived quality terhadap loyalitas pelanggan dengan tingkat signifikansi $0.038<0,05$ dan t.-hitung 1.998> t-tabel 1.9839, maka teori penelitian telah sejalan dengan empiris. Besaran pengaruh persepsi kualitas terhadap loyalitas pelanggan adalah 0.204 atau $20.4 \%$.

\section{Tabel 2 : PengaruhPerceived Quality} Terhadap Loyalitas Pelangan

\begin{tabular}{|c|c|c|c|c|c|}
\hline \multirow{3}{*}{ Model } & \multicolumn{2}{|c|}{$\begin{array}{c}\text { Unstandardized } \\
\text { Coefficients }\end{array}$} & $\begin{array}{c}\text { Standardized } \\
\text { Coefficients }\end{array}$ & $\mathrm{t}$ & Sig. \\
\cline { 2 - 5 } & $\mathrm{B}$ & $\begin{array}{c}\text { Std. } \\
\text { Error }\end{array}$ & Beta & & \\
& $\mathrm{B}$ & & & \\
\hline
\end{tabular}




\begin{tabular}{|l|l|l|l|l|l|}
\hline $\begin{array}{l}\text { Perceiv } \\
\text { ed_Qua } \\
\text { lity }\end{array}$ & 0.197 & 0.110 & 0.204 & 1.998 & 0.038 \\
\hline
\end{tabular}

Sumber : Output SPSS Diolah

Hal ini berarti sejalan dengan hasil penelitian Ahmad Kholid Alghofari, at.all (2009), yang menyimpulkan bahwa persepsi kualitas (perceived quality) memiliki pengaruh signifikan terhadap Customer Loyalty pada jenis Merk Pasta Gigi,

Indikator variabel perceived quality tertinggi memengaruhi loyalitas pelangan dengan koefisein sebesar 3.70 yaitu Bank Panin Dubai Syariah cabang Palembang juga memberikan solusi dan layanan untuk tabungan Haji dan Umrah.

Sedangkan indikator variabel perceived quality yang paling rendah nilai koefisienya sebesar 2.93 yaitu Bank Panin Dubai Syariah memberikan solusi finansial bagi nasabah yang dikelola secara Syariah.

Indikator dari variabel loyalitas pelanggan yang paling dominan memengaruhi variabel adalah Fasilitas Pinjaman di Bank Panin Dubai Syariah melayani kebutuhan pendanaan untuk keluarga atau bisnis dengan koefisien 3.61 dan indikator terendah variabel loyalitas pelangan sebesar 3.36 yaitu menjadi nasabah Bank Panin Dubai Syariah cabang Palembang merupakan satu-satunya alternatif.

\section{Analisis Pengaruh Brand Loyalty Terhadap Loyalitas Pelangan}

Melalui uji hipotesis bahwa diketahui brand loyalty merk berpengaruh terhadap loyalitas pelangan dengan tingkat signifikansi $0,26<0,05$ dan t. hitung 2.219> t.tabel 1.9839, maka secara teori dan empiris di lapangan dapat dibuktikan.
Besaran pengaruh Brand loyalty terhadap loyalitas pelangan adalah 0.133 .

Tabel 3 : Pengaruh Brand LoyaltyTerhadap Loyalitas Pelangan

\begin{tabular}{|l|c|c|c|c|c|}
\hline \multirow{2}{*}{ Model } & \multicolumn{2}{|c|}{$\begin{array}{c}\text { Unstandardized } \\
\text { Coefficients }\end{array}$} & $\begin{array}{c}\text { Standardized } \\
\text { Coefficients }\end{array}$ & $\mathrm{t}$ & Sig. \\
\cline { 2 - 6 } & $\mathrm{B}$ & $\begin{array}{c}\text { Std. } \\
\text { Error }\end{array}$ & Beta & & \\
\hline Brand_Loyalty & 0.227 & 0.104 & 0.133 & $\begin{array}{c}2.21 \\
9\end{array}$ & $\begin{array}{c}0.02 \\
6\end{array}$ \\
& & & & 9 & \\
\hline
\end{tabular}

Sumber : Output SPSS Diolah

Penelitian didukung penelian Ainur Rofiq, at.all (2009), bahwa pada Industri Telepon Seluler bahwa Loyalitas Merk memiliki pengaruh signifikan terhadap Loyalitas Pelanggan.

Indikator variabel loyalitas merk yang terendah dalam memengaruhi variabel loyalitas pelangan adalah Produk bank syariah sudah menjadi pilihan utama nasabah. Disini dapat dimaknai bahwa masyarakat Palembang belum menjadikan Bank Syariah sebagai pilihan untuk berinvestasi.

Sedangkan indikator variabel brand loyalty yang paling menonnjol dengan koefisien sebesar 3.97 yaitu Produk bank Syariah sesuai dengan kondisi sosial masyarakat Palembang yang dikenal agamis. Sesungguhnya sudah ada pemahaman bahwa produk bank Syariah sudah sesuai dengan kondisi social masyarakat Kota Palembang, namun disayangan bahwa produk bank Syariah belum menjadi pilihan utama.

\section{Analisis Pengaruh Brand Association terhadap Loyalitas Pelangan}

Melalui uji hipotesis bahwa diketahui bahwa brand associationmemengaruhi loyalitas pelanggan dengan tingkat signifikansi $0,00<0,05$ dan thitung 3.699> t.tabel 1.9838, maka teori dan empiris di lapangan dapat dikonfirmasi. Besaran 
pengaruh brand association terhadap loyalitas pelangan adalah 0.414 atau $41 \%$.

Tabel 4 : Pengaruh Brand AssociatianTerhadap Loyalitas

Pelangan

\begin{tabular}{|c|c|c|c|c|c|}
\hline \multirow[t]{2}{*}{ Model } & \multicolumn{2}{|c|}{$\begin{array}{l}\text { Unstandardized } \\
\text { Coefficients }\end{array}$} & $\begin{array}{c}\text { Standardized } \\
\text { Coefficients }\end{array}$ & \multirow[b]{2}{*}{$\mathrm{T}$} & \multirow[b]{2}{*}{ Sig. } \\
\hline & B & Std. Error & Beta & & \\
\hline $\begin{array}{l}\text { Brand } \\
\text { _Asso } \\
\text { ciation }\end{array}$ & 0.353 & 0.095 & 0.414 & 3.699 & 0.000 \\
\hline
\end{tabular}

Sumber : Output SPSS Diolah

Penelitian didukung penelitian Ainur Rofiq, at.all (2009), bahwa pada Industri Telepon Seluler: Ekuitas merk memiliki pengaruh signifikan terhadap Loyalitas Pelanggan, di mana Kesadaran Merk, Asosiasi Merk, dan Loyalitas Merk memiliki pengaruh signifikan terhadap Loyalitas Pelanggan.

Indikator variabel brand association yang paling dominan memengaruhi loyalitas pelanggan adalah Produk bank Syariah sudah sejalan dengan dengan ketentuan Syariah dengan koefisien regresi sebesar 3.52, dan indikator terendah adalah dengan koefisien 2.92 yaitu Informasi tentang Bank Syariah di Kota Palembang, membuat nasabah memahami tentang produk bank Syariah.

Rendahnya pemahaman tentang produk Bank Syariah dapat disebabkan kurang gencarnya promosi dari Bank Panin Dubai Sariah Cabang Palembang, namun masyarakat sebenarnya telah memamahi bahwa Bank Panin Dubai Syariah produknya telah sesuai dengan ketentuan syariah.

Analisis Pengaruh Brand Awareness, Perceived Quality, Brand Loyalty, dan Brand Association secara bersama-sama terhadap Loyalitas Pelangan

Melalui uji hipotesis bahwadiketahui Pengaruh Brand Awareness, Perceived
Quality, Brand Loyalty, dan Brand Association secara bersama-sama terhadap Loyalitas Pelangan dengan tingkat signifikansi $0,00<0,05$ dan $\mathrm{F}$ hitung 7,655> F.tabel 2.700, maka secara teori dan empiris di lapangan dapat dibuktikan.

Tabel 5 : Pengaruh Brand Equity

Secara Bersama-Sama Terhadap Loyalty Customer

\begin{tabular}{|c|c|c|c|c|c|}
\hline Model & $\begin{array}{c}\text { Sum of } \\
\text { Squares }\end{array}$ & Df & $\begin{array}{c}\text { Mean } \\
\text { Square }\end{array}$ & F & Sig. \\
\hline 1 & Regression & 4 & 1.934 & 7.665 & $.000^{\mathrm{a}}$ \\
\hline
\end{tabular}

Sumber : Output SPSS Diolah

Besaran Pengaruh Brand Awareness, Perceived Quality, Brand Loyalty, dan Brand Association secara bersama-sama terhadap Loyalitas Pelangan dari out put $R$ Square adalah 0.244 atau sebesar $24,4 \%$. dengan kata lain sebanyak $65,6 \%$ lainnya dipengaruhi oleh variasi beberapa variabel lain di luar dari variabel penelitian. Sebagaimana tersebut dalam table berikut

Tabel 6 : Pengaruh Brand Awareness, Perceived Quality, Brand Loyalty, dan Brand Association secara bersama-sam: terhadap Loyalitas Pelangan

\begin{tabular}{|c|c|c|c|c|}
\hline Model & $\mathrm{R}$ & $\begin{array}{c}\mathrm{R} \\
\text { Square }\end{array}$ & $\begin{array}{c}\text { Adjusted R } \\
\text { Square }\end{array}$ & $\begin{array}{c}\text { Std. Error of the } \\
\text { Estimate }\end{array}$ \\
\hline 1 & $0.494^{\mathrm{a}}$ & 0.244 & 0.212 & 0.502 \\
\hline
\end{tabular}

Didukung oleh Muchsin Saggaff Shihab dan Ananto Sukendar (2009), yang berkesimpulan yaitu variabel brand trust dan variabel Ekuitas merk (Brand Equity) baik bersama-sama dan parsial secara konsisten mempengaruhi Loyalitas Konsumen produk tes widal merk Remel dengan nyata atau signifikan.

Begitu juga hasil penelitian Azka Nabila Islami (2010), bahwa Kesadaran merk (Brand Awareness), Asosiasi merk (Brand association), Persepsi kualitas (perceived quality), dan Loyalitas merk (Brand 
loyalty) dari Handphone Merk Nokia memiliki pengaruh positif dan signifikan terhadap minat beli konsumen.

Penelitian Chan (2010) dengan mengambil studi kasus pada bank muamalat telah menemukan hasil penelitian, bahwa Ekuitas merk Bank Muamalat Indonesia memiliki pengaruh positif dan signifikan terhadap proses keputusan pembelian konsumen.

Indikator dari variabel loyalitas pelanggan yang paling dominan memengaruhi variabel adalah LM04 Fasilitas Pinjaman di PDSB melayani kebutuhan pendanaan untuk keluarga atau bisnis dengan koefisien 3.61 dan indikator terendah adalah LM01 sebesar 3.36 yaitu menjadi nasabah Bank Panin Dubai Syariah cabang Palembang merupakan satu-satunya alternatif.

\section{Kesimpulan Penelitian}

Hasil penelitian dapat ditarik benang merah penelitian bahwa; brand awareness nasabah Bank Panin Dubai Syariah tidak berpengaruh terhadap loyalitas pelanggan, perceivedquality nasabah Bank Panin Dubai Syariah berpengaruh terhadap loyalitas pelanggan, brand loyalty nasabah Bank Panin Dubai Syariah berpengaruh loyalitas pelangan, brand association nasabah Bank Panin Dubai Syariah berpengaruh terhadap loyalitas pelanggan, dan secara bersama-sama brand awareness, perceivedquality, brand loyalty dan brans association nasabah Bank Panin Dubai Syariah bepengaruh terhadap loyalitas pelangan

\section{Implikasi Manajerial}

Implikasi manajerial untuk membangun loyalitas pelangan Bank Panin Dubai Syariah dimulai dengan membangun asosiasi merk pelangan dengan mengelola
Bank Syariah sesuai dengan dengan ketentuan Syariah, kemudian meningkatkan persepsi kualitas pelangan dengan menjadikan Bank Panin Dubai Syariah Cabang Palembang memberikan solusi dan layanan untuk tabungan Haji dan Umrah, serta mempertahankan loyalitas merk produk Bank Panin Dubai Syariah sesuai dengan kondisi sosial masyarakat Palembang yang agamis, semoga!

\section{Daftar Pustaka}

Aaker, David A.1991.Managing Ekuitas merek (Brand Equity). The Free Press and Co. $20^{\text {th }}$ Edition. New York.

Alghofari, Ahmad Kholid. Pratiwi, Indah. Astuti, Purbosari Yudha. 2009. Analisis Pengaruh Ekuitas merek (Brand Equity) Terhadap Pembentukan Customer Loyalty Pada Jenis Pasta Gigi Dengan Analisis SEM (Studi Kasus Mahasiswa UMS). Simposium Nasional RAPI VIII Universitas Muhammadiyah Surakarta. Surakarta.

Arikunto, S. 2003. Prosedur Penelitian: Suatu Pendekatan Praktek. Rineka Cipta. Jakarta.

Chan, Arianis. 2010. Pengaruh Ekuitas merek Terhadap Proses Keputusan Pembelian Konsumen: Studi Kasus Bank Muamalat Indonesia Cabang Bandung. Jurnal Administrasi Bisnis. Vol.6, No.1: hal.43-58.

Durianto,Darmadi. Sugiarto. 2004. Ekuitas merek (Brand Equity) Ten: Strategi Memimpin Pasar. Gramedia Pustaka Utama.

Farquhar, P.H. 1990. Managing Ekuitas merek (Brand Equity). Journal of Advertising Research. Vol.30. August- September, pp. RC7-RC12. 
Fitria,Santi. 2012. Pengaruh Ekuitas merek pada keputusan pembelian produk mie instan merek Indomie.

Hasan, Ali. 2008. Marketing. Media Utama. Yogyakarta.

Hazra, Sandip Ghosh. Kumar, Tapan. Piyush, Prashant. 2013. Customer Loyalty in Indian Banking Sector: A Comparative Study. International Journal Of Management 2013: 4, 236243.

Islami, Azka Nabila. 2010. Analisis Pengaruh Kesadaran merek (Brand Awareness), Asosiasi merek (Brand association), Persepsi kualitas (perceived quality), dan Loyalitas merk (Brand loyalty) Terhadap Minat Beli Telepon Seluler Nokia (Studi Kasus pada Mahasiswa Fakultas Ekonomi Universitas Diponegoro Semarang). Semarang.

Kapferer. 2008. The New Strategic Brand Management: Creating and Sustaining Ekuitas merek (Brand Equity) Long Term- $4^{\text {th }}$ edition. Great Britain. MPG Books Ltd, Bodmin, Cornwall.

Kaplan, Robert M. Saccuzzo, Dennis P. 1993. Phsycological Testing principles, application, and issues; Brooks/Cole Publishing Company, Pacific Grove,California.

Keller, Kevin Lane. 2008.Strategic Brand Management:Building,

Measuring,and Managing Ekuitas merek(Brand Equity). 3th ed. Upper Saddle River. New Jersey: Pearson Education. Inc.

Knapp, Duane E. Hart, Christopher W. 2000. The Brand Mindset. McGrawHill. New York.

Kotler, Philip. Keller, Kevin Lane. 2012. Marketing Management. Pearson Education Limited 14 e. New Jersey.
Rofiq, Ainur. Suryadi, Nanang. Faidah, Nita Nur. 2009. Peranan Ekuitas merek Terhadap Loyalitas Pelanggan Pada Industri Telepon Seluler. The $3^{\text {rd }}$ National Conference on Management Research. Bandung.

Shihab, Mukhsin Saggaff. Sukendar, Ananto, 2009. Pengaruh Brand Trust dan Ekuitas merek (Brand Equity) Terhadap Loyalitas Konsumen Studi Kasus Produk Tes Widal Merek Remel. Jurnal Ilmiah Manajemen Bisnis Dan Terapan Tahun VI No 2, Oktober 2009

Sugiyono. 2003. Metode Penelitian Bisnis. CV. Alfabeta. Bandung.

Tapeci, Mustafa. 2014. Increasing Loyalitas merek (Brand loyalty) in The Hospitality Industry. International Journal of Contemporary Hospitality Ma. 